\title{
Os Xetá e seus acervos: memória histórica, política e afetiva (Paraná, Brasil)
}

Les Xetá et leurs collections: une mémoire historique, politique et affective (Paraná, Brésil)

The Xetá and their collections: historical, political and affective memory (Paraná, Brazil)

Edilene Coffaci de Lima, Lilianny Rodriguez Barreto dos Passos e Rafael Pacheco

\section{OpenEdition}

\section{Journals}

Edição electrónica

URL: https://journals.openedition.org/jsa/19503

DOI: 10.4000/jsa. 19503

ISSN: $1957-7842$

\section{Editora}

Société des américanistes

\section{Edição impressa}

Data de publição: 30 setembro 2021

Paginação: 127-150

ISSN: 0037-9174

Refêrencia eletrónica

Edilene Coffaci de Lima, Lilianny Rodriguez Barreto dos Passos et Rafael Pacheco, «Os Xetá e seus acervos: memória histórica, política e afetiva (Paraná, Brasil) », Journal de la Société des américanistes [En ligne], 107-1 | 2021, mis en ligne le 30 septembre 2021, consulté le 02 septembre 2022. URL http://journals.openedition.org/jsa/19503 ; DOl : https://doi.org/10.4000/jsa.19503

Este documento foi criado de forma automática no dia 2 setembro 2022.

Tous droits réservés 


\section{Os Xetá e seus acervos: memória histórica, política e afetiva (Paraná, Brasil)}

Les Xetá et leurs collections : une mémoire historique, politique et affective

(Paraná, Brésil)

The Xetá and their collections: historical, political and affective memory (Paraná, Brazil)

Edilene Coffaci de Lima, Lilianny Rodriguez Barreto dos Passos e Rafael Pacheco

\footnotetext{
"As we produce 'things,' so our concern is with preserving things, products and techniques of their production. Our Culture is a sum of such things: we

keep the ideas, the quotations, the memoirs, the creations, and let the people go." Roy Wagner, The invention of culture (1975, p. 26)
}

\section{Prólogo}

1 Os Xetá (conhecidos também como Setá, Chetá, Hetá, Aré, Ñadereta, entre outros), povo indígena falante de uma língua tupi-guarani, tiveram consolidado o contato com os brancos na Serra dos Dourados, no noroeste do estado do Paraná, na metade do século passado (Mota 2013; Silva 1998, 2003). A frente cafeeira avançou sobre seu território e, de forma impiedosa, fragilizou o grupo por meio de envenenamentos, raptos de crianças, remoções forçadas e mortes - uma história tragicamente bem documentada. Naquela ocasião, entre o final da década de 1940 e início de 1960, estimou-se que os Xetá eram no mínimo 200 pessoas, tendo rapidamente reduzida sua população em aproximadamente $70 \%$, segundo estimativa do antropólogo José Loureiro Fernandes (1959). Os eventos em torno do contato dos Xetá foram muito veiculados pela imprensa escrita nacional e internacional, como a revista de notícias estadunidense Time do início de 1959, na seção 
Science - trazendo a anotação de se tratar dos "últimos índios da idade da pedra", sentença repetida inúmeras vezes por pesquisadores como José Loureiro Fernandes, Vladimir Kozák e Annette Laming-Emperaire, e mesmo na documentação administrativa do antigo Serviço de Proteção aos Índios (SPI; Leite 2019). ${ }^{1}$

Diante do avanço da frente cafeeira sobre o território indígena, um grupo familiar estabeleceu contato com colonos da Fazenda Santa Rosa, instalada sobre um dos campos de caça e coleta de grupos familiares naquela região, local onde o SPI montou também um "centro de atração". A partir de então, os pesquisadores da Universidade do Paraná (UPR), José Loureiro Fernandes (professor de antropologia) e Vladimir Kozák (cinegrafista), tiveram papel fundamental ao participarem, entre 1955 e 1961, de expedições de contato e aproximação para encontrá-los, e de expedições científicas, ao cabo das quais ofereceram os primeiros registros e impressões sobre o grupo recémencontrado. Ambos também acionaram diversas redes no Brasil e internacionalmente para difundir notícias do violento contato.

3 José Loureiro Fernandes fez denúncias em numerosos congressos, como na IV Reunião da Associação Brasileira de Antropologia, em 1958, e no Congresso dos Americanistas, de 1960, em Viena (Fernandes 1959, 1962), além de interceder por meio de cartas e telegramas junto ao Conselho Nacional de Proteção aos Índios (CNPI) e à Presidência da República. A partir da amizade de Vladimir Kozák com o casal Robert Carneiro e Gertrude Dole, a notícia sobre os Xetá, especialmente sobre o contato, chegou à Unesco, $\mathrm{e}$ o etnólogo suíço Alfred Métraux cogitou a possibilidade de visitá-los na Serra de Dourados. ${ }^{2}$

4 Além de Loureiro Fernandes e Kozák, participaram da equipe de pesquisa científica da Universidade do Paraná (UPR) Ney Barreto, à época estudante de geografia; Céstmir Loukotka (1958), linguista tcheco; Aryon Dall'Igna Rodrigues (1960 e 1961), linguista e então professor de tupi-guarani na UPR; e Annette Laming-Emperaire (1960 e 1961), arqueóloga e pesquisadora do Centre national de la recherche scientifique (CNRS, França). Os meninos Kaiuá e Tuca (Figura 1), após raptados por agrimensores e servidores do SPI em 1952 e 1953, respectivamente, passaram a servir de guias no interior da floresta, acompanhados do proprietário e administrador da Fazenda Santa Rosa, jornalistas, fotógrafos, mateiros e agrimensores que realizavam trabalhos na região. 
Fig. 1 - Kaiuá e Tuca com o prof. José Loureiro Fernandes, servindo de guias e intérpretes à equipe da expedição do SPI

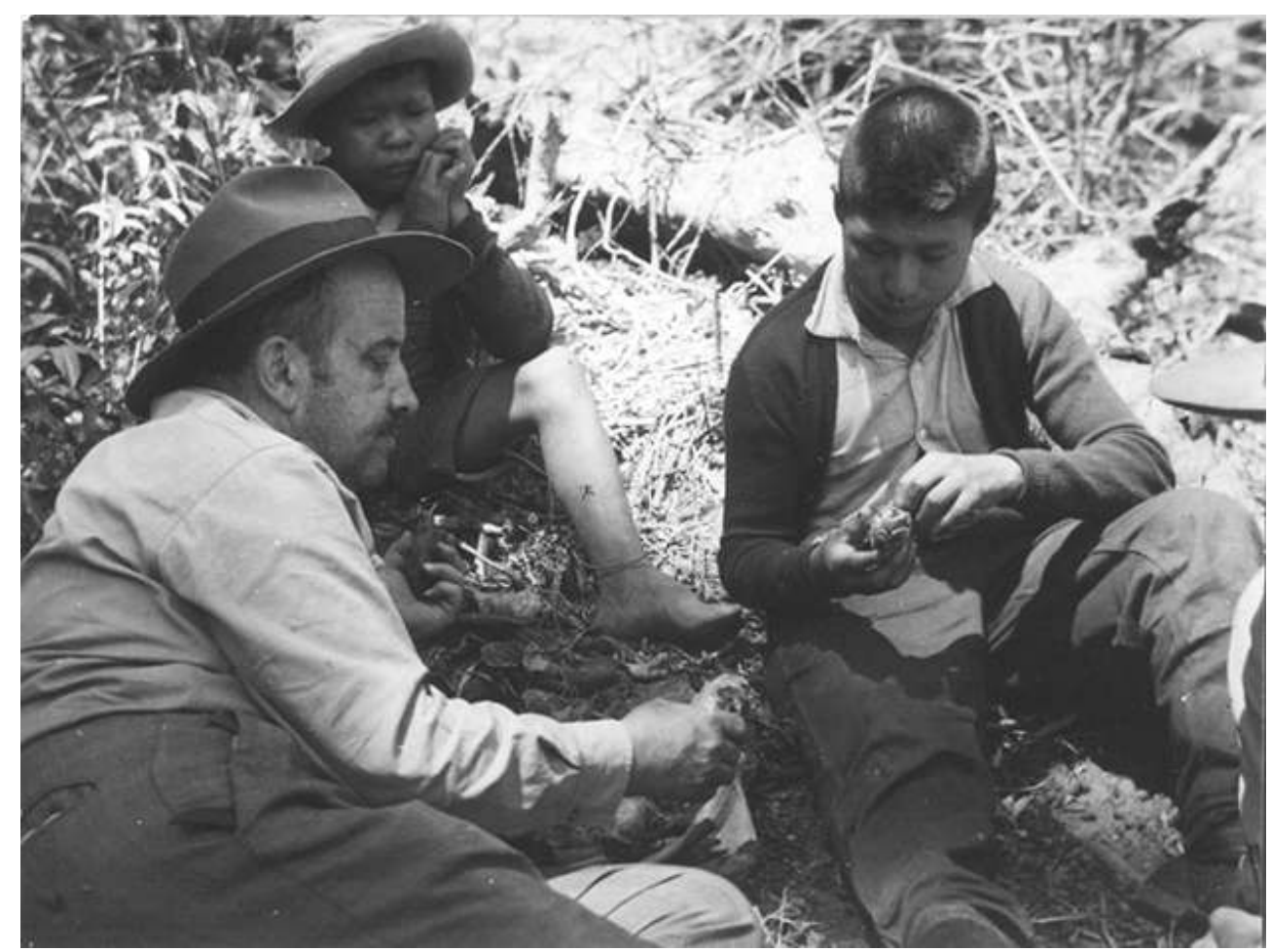

(foto Vladimir Kozák, 1955, acervo MAE/UFPR)

5 Dessas ocasiões abundam anotações de campo e dados sobre organização social, subsistência, ritual; bem como informações linguísticas, narrativas míticas e cantos gravados na língua materna; um rico acervo iconográfico com fotos e filmagens em $16 \mathrm{~mm}$ (Fernandes 196-). Dos grupos familiares que se aproximaram da fazenda, os pesquisadores coletaram artefatos e constituíram as coleções hoje conhecidas.

6 Parte desses objetos foram incorporados por Loureiro Fernandes ao Departamento de Antropologia da UPR, onde permaneceram até o ano de 1994, quando foram transferidos para o Museu de Arqueologia e Etnologia da Universidade Federal do Paraná (MAE/ UFPR), instituição na qual se encontram atualmente, junto à coleção arqueológica de Laming-Emperaire. Kozák também constituiu uma coleção nos mais de vinte anos de contato com os grupos familiares Xetá (Benetti 2016), para a qual, após a sua morte, em 1979, o Museu Paranaense (Mupa) foi designado curador. O Mupa recebeu também a doação de objetos arqueológicos e de cultura material coletados por Ney Barreto.

7 Apesar da ampla divulgação do contato dos Xetá com os brancos - estes últimos referidos como "civilizados" pelos autores -, medidas efetivas não foram tomadas pelos governos federal e estadual a fim de conter a tragédia em curso, amparados que estavam na ideia popularmente difundida de que os indígenas sucumbiam por falta de resistência imunológica a vírus desconhecidos. Os sobreviventes xetá em contato com o SPI foram dispersos por seus funcionários em terras indígenas em outras localidades, entre os Guarani (Tupi-guarani) e Kaingang (Jê), estes com histórico mais longo de contato com populações não indígenas do entorno. Inicialmente, vários deles foram levados para a Terra Indígena Marrecas, popularmente conhecida como Marrecas dos Índios. Não demorou para os Xetá serem dados oficialmente como "extintos". 
Interagindo com os Xetá e os colonizadores, Loureiro Fernandes e Kozák legaram importantes registros (artigos, cadernetas de campo, cartas, mapas, fotos, filmes e objetos recolhidos em campo), fundamentais para a compreensão do trágico enredo na Serra dos Dourados. Como mencionado antes, hoje os objetos que coletaram e os documentos que produziram se encontram em acervos de instituições acadêmicas e de museus de Curitiba, tornando-se perceptível a sua conversão em registros históricos, mobilizados pelos Xetá e por pesquisadores para fundamentar narrativas e pleitos reivindicatórios (Lima 2018; Lima e Pacheco 2017b).

9 Neste contexto de luta $a^{3}$ pela terra, que lhes possibilitasse o retorno - é importante dizer que, desde seu deslocamento forçado, os Xetá não vivem em suas terras originárias -, tornaram-se decisivos os acervos etnográficos e documentais depositados no Mupa, no MAE/UFPR, no Círculo de Estudos Bandeirantes (CEB) e no Centro de Estudos e Pesquisas Arqueológicas (CEPA/UFPR), instituições localizadas em Curitiba, para o encaminhamento de reivindicações territoriais e reparatórias. Tais acervos foram igualmente fundamentais às pesquisas nos campos do direito para a memória da justiça de transição, como as da Comissão Nacional da Verdade (CNV 2014) e da Comissão Estadual da Verdade do Paraná Teresa Urban (CEV-PR 2017), relativas às histórias de povos indígenas no período da ditadura civil-militar (1964-1988) no Brasil.

Os Xetá contemporâneos, descendentes das crianças retiradas da Serra dos Dourados, são filhos de relações com pessoas kaingang, guarani e não indígenas, com os quais formaram famílias e convivem desde o desterro. Atualmente, 200 pessoas se reconhecem Xetá, ainda que misturados com seus corresidentes, dado o fato de que jamais puderam voltar para suas terras originárias, restando inconcluso pelo Estado brasileiro o processo demarcatório da Terra Indígena Herarekã Xetá (Funai 2013), corrente há mais de vinte anos e objeto de disputa judicial, envolvendo a dedicação de suas lideranças na mobilização política.

11 Hoje, a maioria dos Xetá reside na TI São Jerônimo, originariamente terras kaingang na bacia do rio Tibagi, no norte do estado do Paraná. Ali, a maior parte dos residentes é aparentada com Tikuein. $\mathrm{O}$ segundo grupo xetá mais populoso está na aldeia urbana Kakané Porã, em Curitiba, cujos moradores são aparentados com Tuca. Ambos os patriarcas faleceram no início dos anos 2000. Em menor número, outras famílias xetá vivem em terras indígenas e cidades nos estados de Paraná e Santa Catarina (Figura 2) havendo ainda notícias esparsas de possíveis sobreviventes, mas de localização incerta. 
Fig. 2 - Localização geográfica atual dos Xetá

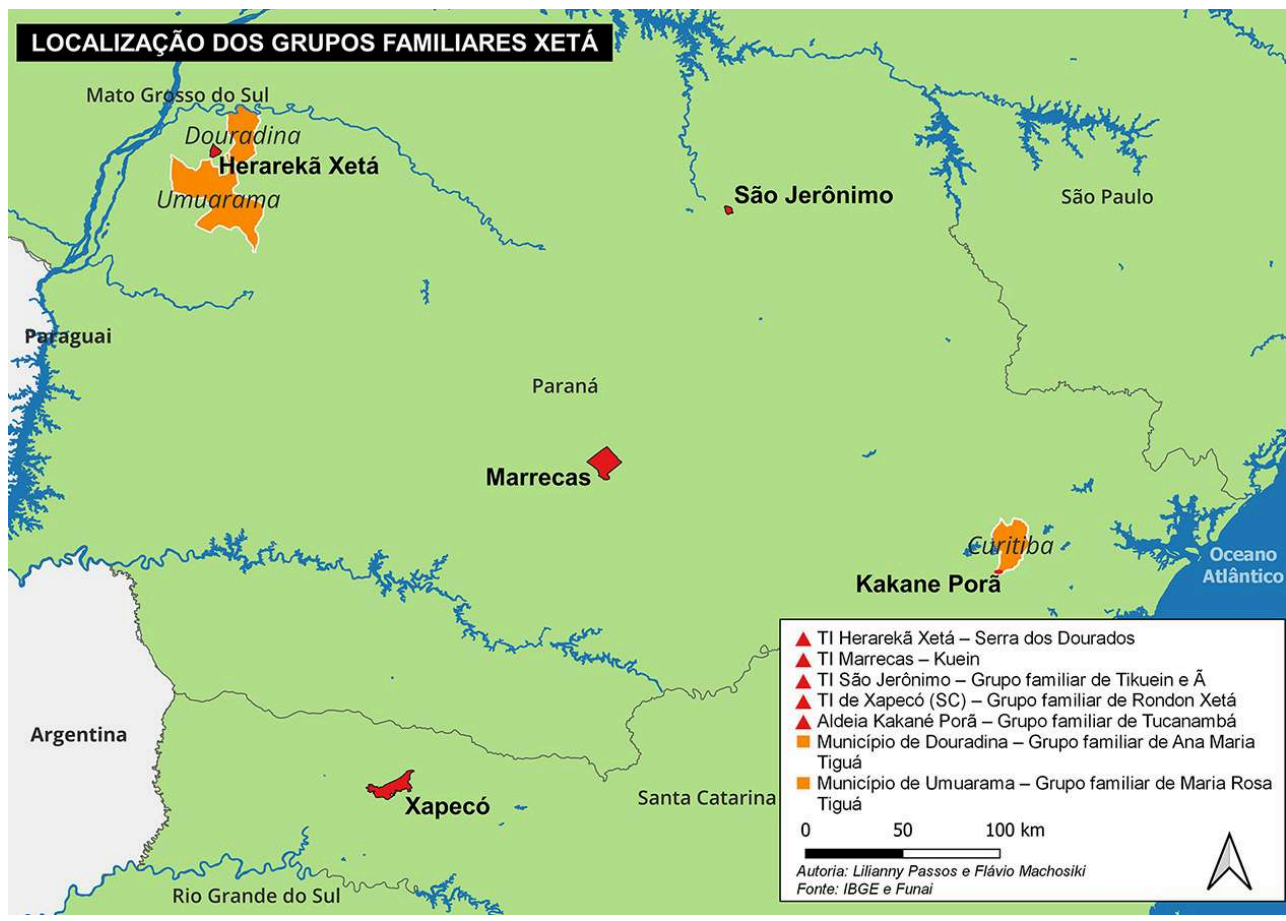

(mapa Lilianny R. B. Passos, Flávio Machosiki. Fonte: IBGE e Funai)

Um dos efeitos da separação forçada foi a perda e a redução linguística, tornando a língua xetá atualmente ameaçada de extinção, com apenas dois falantes: Kuein, morador em Marreca dos Índios, e Ã, em São Jerônimo, ambos nascidos em Serra dos Dourados. Claudemir, filho do falecido Tikuein, morador de São Jerônimo, conhece rudimentos da língua, aprendida com o pai, e eventualmente pronuncia-se publicamente dela fazendo uso, sobretudo em contextos de relevância política, e com desenvoltura indicativa da falta de interlocutores. Hoje em dia, a totalidade dos Xetá faz uso do português nas interações cotidianas. ${ }^{4}$

\section{A emergência da extinção}

Do que se sabe, principalmente a partir de Kozák (s.d.), no manuscrito A história dos Hetá, foram agrimensores da Companhia Colonizadora Suemitsu Miyamura Ltda., colônia de imigrantes japoneses, os primeiros a dar a notícia de índios naquelas imediações, fato que motivou a ida, em julho de 1949, do funcionário do SPI Wismar Costa Lima Filho para averiguar informações.

Daí em diante, a $7^{\mathrm{a}}$ Inspetoria Regional do SPI (7IR/SPI), desde Curitiba, organizou e realizou expedições de "contato e aproximação" com os Xetá, parte delas em colaboração com o Instituto de Pesquisas (IP) da Universidade do Paraná. Todas pouco planejadas, na avaliação de Kozák, resultando no adiamento do encontro definitivo, àquela altura inevitável.

Para a efetiva invasão e usurpação do território indígena foram postas em prática estratégias e técnicas violentas, envenenamento de comida e rapto de crianças especialmente, entre outras, que resultaram na eliminação progressiva da presença dos Xetá, submetidos ao avanço dos pioneiros. Como antes mencionamos, a maioria dos 
adultos sobreviventes foi deslocada para Marreca dos Índios, local destinado às famílias kaingang e guarani no centro-sul paranaense, nas imediações do município de Guarapuava.

16 Já expulsos os Xetá de Serra dos Dourados, planejou-se - inclusive com os esforços de Loureiro Fernandes e outros intelectuais paranaenses - a demarcação de uma pequena parcela do seu território realmente ocupado, dentro dos limites do Parque Nacional de Sete Quedas, criado pelo governo federal em 30 de maio de 1961, reconhecendo-se os direitos territoriais dos Xetá, além da preservação ambiental, das "belezas" naturais, fauna e flora. ${ }^{5}$

17 Ao mesmo tempo, o Estado reputava aos Xetá status de "extintos", abstendo-se de medidas para reagrupar e reassentar os remanescentes dispersos - não parece excessivo especular que àquela altura eles sequer soubessem que terras lhes foram reconhecidas. $\mathrm{A}$ indiferença estatal tem culminância em 1981, com decreto do General João Batista de Oliveira Figueiredo extinguindo o Parque, cujas terras foram inundadas no ano seguinte pelas águas do reservatório da Usina Hidrelétrica Itaipu Binacional (CEV-PR 2017; CNV 2014; Silva 1998). Após o início do funcionamento da usina, prevaleceram o silêncio, o desterro e a imagem dos Xetá como a de um povo "em vias de extinção".

Por toda a década de 1960 as poucas notícias sobre os Xetá vinham dos escritos de Loureiro Fernandes e Kozák, ambos convencidos da inevitável extinção dos poucos que haviam sobrevivido ao avanço da colonização, desterrados e fragilizados.

Na década de 1970, com poucos anos de diferença, faleceram Loureiro Fernandes e Kozák e tornaram-se raras então as veiculações de informações sobre os Xetá, que caíram, por assim dizer, no esquecimento - como fora anotado no relatório da CNV. O "esquecimento" alcançou proporções superlativas, sobretudo nas três últimas décadas do século $x x$, engendrando uma imagem que continuou a ser reproduzida até bem recentemente. A compreensão de que os Xetá estavam em "risco de extinção" torna-se uma condição permanente e atravessa décadas.

20 Foi apenas próximo da virada do século que esse quadro se alterou, e para isso foram determinantes as pesquisas de Carmen Lúcia da Silva (1998 e 2003), que reuniu os "sobreviventes", como resultado de sua investigação. Naquela ocasião, ela conseguiu encontrar, em diferentes localidades, oito deles, além de seus filhos e netos.

\section{Formação e dispersão de acervos etnográficos}

21 No MAE/UFPR, a coleção etnográfica Xetá, constituída por José Loureiro Fernandes, é composta por 104 objetos, como pilões, recipientes de espata de palmeira, flechas, arcos circulares e elipsolidais, bordunas, brincos de penas de aves, colar, cestos, peneiras, abanos, tipoias, tanga tecida de fibra vegetal, flautas, perfuradores labiais, paus ígneos, cuia de cabaça, cabos de machado de pedra, travesseiros de madeira, estojo de folha de palmeira, diadema de cauda de macaco e formões de osso de animal, entre outros. Além disso, amostras de solução de jenipapo; sementes pretas; frutos de jatobá; ervas; embira de caraguatá; resina de cera de abelha, jatobá; folha de palmeira trançada; armadilhas mundéu; fio de algodão; fragmentos de colares; crânios, peles e unhas de animais, tais como quati, tatu e lontra. Ainda no MAE, as coleções de material lítico xetá, formadas a partir da pilhagem ${ }^{6}$ em expedições científicas, totalizam 181 peças, organizadas em duas coleções: 127 peças estão identificadas na coleção Loureiro Fernandes, na qual está um 
crânio humano, e 54 peças compõem a coleção Annette Laming-Emperaire (Merencio 2014).

22 Na Unidade de Documentação Textual, Sonora e Visual (Unidov) do MAE/UFPR, encontra-se um arquivo documental, em diferentes suportes, constituído por 654 registros fotográficos; quatro mapas (Souza 2017, p. 11); cópias do filme Os índios da Serra dos Dourados em bitola $16 \mathrm{~mm}$ e em VHS; rolos de gravações magnetofônicas de áudio - incluindo a edição do filme em francês realizado pelo Museu do Homem de Paris (Passos 2021, p. 30).

Entre os objetos que compõem a coleção Xetá no Mupa, constituída por Vladimir Kozák, destacam-se 296 peças, entre as quais estão (em listagem não exaustiva) 138 figuras zoomorfas feitas em cera negra com retoque final de cinza; bordunas em formato de remo, lanças de bambu, arcos, flechas, esteiras, abanadores de folhas de palmeira, pegadores de brasa, peneiras, cestos, cabaça, pilão horizontal, machados de pedra, agulhas para tecer, fusos de cera, flautas, pele de onça, tembetás de resina e madeira, brincos de plumária, colares de dentes de animais, adornos de rabo de macaco, tangas tecidas de fibra vegetal e perfuradores labiais de dentes de animal.

24 No total, somados com objetos coletados por outros pesquisadores, no Mupa estão depositadas 523 peças de cultura material (Parellada 2017). Ali se encontram ainda peças confeccionadas pelos Xetá contemporaneamente, elaboradas durante a realização de projetos culturais colaborativos, totalizando 78 produzidas nas oficinas que tiveram lugar entre os anos de 2010 e 2013 (ibid.).

Entre os documentos da Coleção Vladimir Kozák estão 12 filmes em $16 \mathrm{~mm}$, com aproximadamente 12.000 pés de gravações; 1.283 fotografias (Rosato 2009, p. 7) e 13 cadernetas de campo, em que registrou suas relações com os grupos familiares xetá durante as expedições científicas à Serra dos Dourados, na Fazenda Santa Rosa, nos postos de Marrecas e Pinhalzinho, e em sua casa, na cidade de Curitiba; 2.428 diapositivos, transparências e negativos; 18 imagens de óleo sobre tela, em que retratou cenas cotidianas da vida xetá; 28 desenhos em giz sobre papel.

26 O arquivo documental de Loureiro Fernandes no CEB contabiliza 4.136 documentos textuais digitalizados, de cunho pessoal e institucional. Deste total, aproximadamente 265 documentos textuais tratam de diferentes assuntos referentes aos Xetá, envolvendo expedições, informações etnográficas sobre os grupos familiares; o processo de aproximação e identificação; solicitação de objetos para sua coleção; roteiros dos filmes; projetos de pesquisa antropométrica; e exposições científicas. Boa parte de seus documentos textuais trata da sua intenção de criação do Parque Nacional de Sete Quedas.

No Centro de Pesquisas Arqueológicas da UFPR (CEPA/UFPR), também criado por Loureiro Fernandes em 1956, encontram-se pastas com documentos a ele pertencentes (cartas, ofícios, relatórios, jornais, artigos) referentes à atuação política, jornais e revistas com informações das expedições e das exposições científicas organizadas pelo antropólogo. Há cópias em fita VHS do filme Os Xetá na Serra dos Dourados e três fitas K7 possivelmente parte do arquivo linguístico constituído por Aryon Dall'Igna Rodrigues em suas pesquisas.

O volume da documentação sobre os Xetá em papel impressiona - sobretudo os pesquisadores -, conforme apontam Lima e Leite (2019, p. 5), que estimaram a existência de cerca de 900 arquivos sobre os Xetá, a maior parte em Curitiba, sem considerar, portanto, o que deve haver em cidades menores (Mota e Faustino 2018), nas 
proximidades de seu território tradicional, constituídas a partir da sua usurpação - como é o caso de Douradina, Ivaté e Umuarama, entre outras.

O conjunto dos acervos tem dimensão monumental, compreensível ao se considerar o fato de que, nas décadas de 1950 e 1960, os Xetá viveram regularmente com pesquisadores em seu entorno - antropólogos e linguistas especialmente, historiadores e arqueólogos, sendo essa monumentalidade em parte efeito dessas relações. Dadas os estreitos vínculos estabelecidos e a sua antiguidade, familiarizaram-se com a presença de pesquisadores, que acaba se tornando, de certo modo, "histórica".

Em todo o conjunto de materiais, a violência é pregnante. Constituídos à época do contato, tais acervos etnográficos foram formados no mesmo momento em que as terras eram ocupadas e os índios massacrados ou "extraviados", e por muito tempo foram considerados aquilo que foi possível salvar da destruição (Souza 2017). Os registros elaborados por Vladimir Kozák e José Loureiro Fernandes documentam a ação genocida promovida pelos cafeicultores pioneiros sob o silêncio e a omissão do Estado e podem figurar, além de registros históricos de teor cultural, como documentação comprobatória de violações de direitos, quando a história xetá é objeto de controvérsias históricas propriamente, bem como políticas ou judiciais (Lima 2016; Lima e Pacheco 2017a; Pacheco 2018).

31 Transcorridas décadas de diálogos e parcerias, cabe agora à antropologia observar como se dá o acesso e a conservação dos materiais produzidos por tantos pesquisadores, o que aqui apenas se ensaia. A novidade reside justamente na apropriação que agora os Xetá vêm fazendo deles, realizando neles suas próprias investigações, tomando as coleções e seus conteúdos por objetos de conhecimento, articulando-os a projetos de pesquisa científica, políticas culturais e práticas de documentação e acervo em nível pessoal e institucional.

Um dos usos desses materiais feito pelos próprios Xetá recentemente, quando passaram a visitar os museus onde estão depositados os objetos de seu povo, é utilizando-os como matriz referencial para a produção de novos objetos culturais, especialmente livros, filmes e artesanatos, estes últimos sendo peças de arte decorativa, adornos corporais e utensílios, manufaturados (colares, animais em miniatura de madeira, cestos e outros), produzidos para comercialização e, em geral, tidos como representativos da cultura xetá. E a ideia dos acervos como matriz referencial se percebe na iniciativa de Dival (filho de Tikuein, uma das crianças retiradas no mato), por exemplo, que passou a confeccionar colares de nó-de-pinho (Araucaria angustifolia) e resina vegetal e a talhar miniaturas de animais em madeira, os bichinhos, inspirados em peças assemelhadas vistas em Curitiba, "copiando-as". Especificamente no artesanato, têm-se por referência os objetos autênticos, referidos àqueles produzidos pelos Xetá e coletados em Serra dos Dourados e que lhes oferecem modelos, que designamos matrizes referenciais, mas cujas formas finais são propriamente derivações.

As "cópias" se fazem com alterações no formato e nos materiais utilizados para sua elaboração. Assim, o colar sipál tradicional, em formato de arco com uma haste reta na frente cravada de dentes de quati, cede à forma circular do atual, feito com cordão de fibra sintética industrializada, no qual se prendem pontas de nó de pinho polidos; os bichinhos ampliam as possibilidades representativas dos antigos möw de formas antropozoomórficas e de animais do convívio para animais não necessariamente presentes no cotidiano, como onças, girafas, araras e macacos, além de objetos e utensílios (como pilões, machados, escudos de times de futebol), numa profusão de 
imagens e incremento de técnicas. ${ }^{8}$ Nos dois casos alteraram-se as matérias-primas para a confecção dos objetos: nós-de-pinho no lugar de dentes de animais, nos colares; madeira, em vez de cerume de abelha, para as miniaturas.

Os processos criativos contemporâneos, assim, incrementam-se em dois vetores, primeiro, a atualização de saberes a partir do encontro com os antigos objetos musealizados, depois, a ampliação do repertório de materiais e técnicas de produção, associada à relação entre a criatividade do artesão e a conjuntura material.

\section{Do museu à aldeia: os acervos repatriados digitalmente}

Em São Jerônimo, os filhos de Tikuein (Mã) dizem que o pai lhes deixou conhecimentos e atribuições específicas: para Dival, o filho mais velho, deixou as histórias; para Claudemir, o segundo filho, os conhecimentos de língua, cantos e o preparou para a liderança política; para as mulheres, deixou os conhecimentos do trançado. Além disso, os filhos se lembram de uma série de conhecimentos transmitidos pelo pai, compreendendo os cuidados com as crianças, as plantas, os animais e as relações familiares e, sobretudo, que os alertou para o fato de que "uma hora vocês vão precisar dessas histórias".

Destaca-se que os irmãos Dival e Claudemir são bastante interessados pelos acervos museais que lhes dizem respeito, tendo tal ação por efeito a reativação desses objetos no convívio dos Xetá, em termos de sua circulação material, usos e mesmo como dispositivo de subjetivação, isto é, concorrendo para a constituição de sua memória e identidade pessoal e coletiva. $O$ acervo imagético de Kozák guardado no Mupa (do qual solicitaram e obtiveram cópias digitalizadas de alguns itens em visita em maio de 2017) e o acervo de cultura material com o qual vêm trabalhando no MAE/UFPR são especialmente visados, e há alguns anos podemos acompanhar etnograficamente tais processos.

Dival sucedeu seu irmão Claudemir na liderança (política) ${ }^{9}$ de São Jerônimo, quando este decidiu se afastar, substituindo-o e assumindo também a presidência da Associação Indígena da Etnia Xetá (Aiex). Nestas posições, enquanto cacique, ele é responsável por organizar os trabalhos, atividades políticas, regulativas, econômicas, de mediação e outras, que envolvem, em um nível, seu grupo familiar extenso (cônjuges, filhos e filhas, noras, genros, irmãos e irmãs, sobrinhos e sobrinhas, netos e netas, cunhados, cunhadas etc.), e em nível mais abrangente, a população residente na TI São Jerônimo, a comunidade.

Como guardião das histórias e responsável pelos trabalhos, Dival é encarregado do recebimento e da guarda dos acervos digitais, CDs, DVDs, pendrives e todo e qualquer material relativo aos Xetá. A destinação dos acervos digitais no interior da TI parece seguir critérios definidos pela liderança, uma posse que devemos ainda melhor etnografar. De todo modo, é notável a orientação de Dival a uma pesquisadora: quando esta lhe entregou um $\mathrm{CD}$, aconselhou-a a destinar o material primeiramente a Claudemir, pois seria ele o guardião da língua.

Tanto em São Jerônimo como em Kakané Porã, os Xetá praticam o colecionismo e a guarda de materiais em arquivos domésticos. Dival, ao abrir um dos seus, percorreu distintos tempos em múltiplas histórias: os processos protocolados na Secretaria de Estado da Educação do Paraná solicitando recolhimento de dois livros distribuídos às 
escolas públicas estaduais por conterem informações incorretas sobre os Xetá (no primeiro, são tidos como extintos; no outro, seu pai é apresentado como cacique dos Kaingang); mostra fotografias de quando era jovem e viajava com o pai e os irmãos para trabalhar em fazendas do Mato Grosso do Sul, e ainda fotografias dos seus filhos e netos. Dival pode passar uma tarde inteira conversando com pesquisadores, ao mesmo tempo em que mantém a televisão ligada veiculando imagens dos antigos parentes a partir de uma cópia digitalizada dos filmes de Kozák, que obteve junto ao Mupa.

Frente aos desafios atuais, portanto, vão-se conformando dinamicamente, pela própria organização dos trabalhos, os conhecimentos transmitidos pelo pai Tikuein e pelos patriarcas em geral em novos arranjos materiais e de transmissão, que expressam aspectos de sua organização (e reorganização) sociopolítica e uma possível política de memória contemporânea, estabelecendo-se certos critérios de validação, autenticidade e legitimidade que se encerram no reconhecimento de um conhecedor tal qual um "guardião da memória".

41 Quando questionados se pretendem solicitar o repatriamento dos objetos etnográficos sob a guarda dos museus, as lideranças xetá, sobretudo Dival e Claudemir, nossos principais interlocutores, respondem negativamente, afirmando que lá estariam bem cuidados e guardados, pelo menos enquanto não tiverem as condições e os recursos para o fazerem autonomamente. Entre os planos futuros da Aiex, com efeito, está o ambicioso projeto de construção, em São Jerônimo, ${ }^{10}$ de um centro cultural, ressaltando os Xetá que eles valorizam os acervos que foram formados e que estão hoje nos museus. 0 espaço projetado é pensado como local destinado a arquivo, biblioteca, exposições fotográficas, (re)produção e comércio de peças tidas como representativas da "cultura" xetá - algo que alguns já vêm fazendo voluntariamente - e realização de eventos e festas, bem como recepção e alojamento de visitantes, como os pesquisadores. Destacam ainda que este será o espaço destinado aos acervos repatriados digitalmente.

Em suas casas, diante das fotografias e dos filmes dos antigos, nossos amigos xetá retomam constantemente a consideração sobre a necessidade de reunir suas famílias, de produzir objetos, caçar e contar histórias sobre como viviam e o que faziam os antigos, estendendo o convite aos pesquisadores para registrar e gravar os seus encontros atuais. Não é raro que nossas conversas em campo versem sobre objetos e acervos digitais, que fazem questão de exibir aos visitantes, e no entorno dos quais narram o que deve ter sido a vida no tempo do mato. Registro indelével de suas histórias e da violência sofrida, os acervos potencializam memórias em que, inicialmente percorrendo a experiência cotidiana e concreta nas antigas oka e oka kã (aldeias e acampamentos provisórios), sobressaem narrativas dos sofrimentos causados pela separação e a potencial desagregação dos laços de parentesco, numa espiral emocional, alternando-se momentos de silêncio, riso e choro.

Hoje, os trabalhos de memória organizados pela liderança compreendem as mesmas ações: caminhadas no mato, construção do tápuj (casa), montagem de armadilhas de caça e produção de cestaria; com rostos pintados de preto e vermelho, entoam o canto do (voo do) urubu, carregam arcos e flechas e machados de pedra. Por ocasião da realização do projeto Jané Rekó Paranuhá (O contar de nossa existência), sob a coordenação do professor Lúcio Tadeu Mota, historiador da Universidade Estadual de Maringá, tais trabalhos foram registrados no filme que leva o mesmo título. havendo objeções por parte da liderança à disponibilização de mídias digitais para 
composição de acervos pessoais. A liderança então alcança tais mídias digitais em contato com pesquisadores e, por sua vez, eventualmente os repassa aos parentes interessados em conhecê-los, formando uma rede que se expande do centro à periferia, por assim dizer. Se a formação desses acervos se deu no sentido inverso - ou seja, da periferia para o centro, ou do "mato" para os museus - agora retorna produzindo outras apreensões e outros efeitos. Mais ou menos ao modo dos cantes de ida y vuelta mencionados por Manuela Carneiro da Cunha logo no início de seu Cultura com aspas (2009). No âmbito mais pessoal, os materiais adquirem densos significados, que ultrapassam seu teor político, de representação, visibilidade e garantia de direitos e recursos, estes dados em termos de trabalho e "cultura". A apreensão dos filmes, das fotos e de diversos outros objetos acervados no ambiente doméstico assume um caráter de patrimônio memorial, que se pretende legar às gerações futuras como conhecimento e memória. Possibilitar que os vários parentes curiosos possam conhecê-los, ser fiel ao propósito de Tikuein e atualizar a memória a partir da firme valorização do que aprendeu com os antigos no tempo do mato. De certa maneira, prolongar-lhes a vida. Talvez, diga-se, a circulação digitalizada dos acervos é fazer viver no presente o passado, ou vice-versa.

De certa maneira, as coisas se passam assim porque os acervos digitais, como suportes que guardam as lembranças dos antigos, são concebidos como relíquias ${ }^{11}$ - no evento Primavera dos museus, em 2017, organizado pelo MAE-UFPR, Claudemir referiu-se aos acervos como "riqueza" -, compreendendo-as como objetos valiosos, de valor histórico, aos quais se vinculam afetivamente, pois que atestam seu vigoroso passado - um tempo que não conheceram. ${ }^{12}$

O conjunto das relíquias armazenadas em suas casas é heterogêneo e inclui desde brincos de penas, roupas e fotografias até mesmo trabalhos científicos de seus pesquisadores, que se fizeram amigos ao longo do tempo. Tal apreensão dos objetos - de brincos a teses como relíquias não se restringe aos moradores de São Jerônimo. Kuein, o mais velho dos sobreviventes de Serra dos Dourados, morador hoje da TI Marrecas dos Índios, guarda com zelo um exemplar da monografia monumental Peixe em lagoa seca, de Vladimir Kozák (Kozák et al. 1981), como prova inequívoca da vitalidade perdida de sua gente - o qual fez questão de mostrar e emprestou a uma de nós por ocasião de visita da Comissão Estadual da Verdade (Lima 2018). Em Kakané Porã, a finada dona Belarmina, ex-esposa de Tuca e matriarca dos Xetá dali, formou ao longo da vida uma coleção com documentos diversos relativos aos Xetá - parte foi exposta no Pavilhão Étnico do Memorial de Curitiba, em 2018. Em seu acervo privado, dona Belarmina reunia recortes de jornal, fotografias impressas, textos acadêmicos, publicações, filmes, em formato físico ou digital, em CD e pendrive. Os materiais eram acondicionados em caixas de papelão, pastas e sacos plásticos, e guardados em um lugar reservado, o seu próprio quarto de dormir - a mesma forma que se observa com os arquivos de Dival, em São Jerônimo. Em ambos os casos, tais acervos privados são mobilizados para a colaboração com pesquisadores e exposições públicas em equipamentos culturais ou eventos culturais nas próprias aldeias.

Cabe notar ainda que há diferentes posturas na relação com os objetos e os registros audiovisuais em ambiente público ou doméstico. Assim, diferentemente da postura comedida e séria assumida no interior dos museus, nos quais certa formalidade se impõe, na visualização de filmes em ambiente doméstico comportam-se de forma totalmente diversa, quando, descontraídos, fazem comentários sobre a juventude dos participantes ou sobre suas características físicas - comentários que não raro terminam em brincadeiras jocosas entre os presentes. 


\section{O futuro imperativo da fala no Encontro do Povo Xetá (setembro, 2019)} estabelecido. Nessa ocasião, o encontro foi promovido com o apoio das antropólogas Kimiye Tomasino e Marcolina Carvalho, da Universidade Estadual de Londrina. Mais tarde, em 1997, um segundo encontro aconteceu, no contexto das pesquisas de Carmen Lúcia da Silva ([coord.] 1997), reunindo os Xetá "sobreviventes" e seus familiares em Curitiba, e contou com o apoio do MAE/UFPR e do Instituto Socioambiental (ISA). Dez anos mais tarde, e por ocasião da morte dos líderes Tikuein e Tuca, em 2007, novo encontro ocorreu na região da TI Marrecas dos Índios, cidade de Guarapuava (PR), momento que marca a inserção de Claudemir e Dival no processo de liderança e início das reivindicações em torno de um projeto de educação escolar indígena, em que o acesso e o contato com posteriormente retornando para suas casas. $O$ encontro é a circunstância especial para a formulação de memória, fortalecimento de vínculos de parentesco, partilha de saberes e, sobretudo, oportunidade de "dar corpo" ao povo. Enquanto espaço de construção de uma história comum, que deve ser pronunciada, os encontros colocam a primazia da fala - é preciso contar a história para que ela siga sendo contada... Destaca-se nos encontros o que chamamos de um imperativo da fala, porque a fala aí se apresenta como um antídoto ao esquecimento.

um artifício com que os Xetá enfrentam um dos legados do extermínio, a separação das famílias de parentes, que alimenta o sentimento de "saudade". A dispersão dos parentes em diferentes localidades impôs a saudade como condição permanente, sem contar ainda com a incerteza de existirem outros parentes não localizados e toda a carga emocional decorrente do rememorar tais histórias. Nesse sentido, Benedita, uma das filhas de Tikuein, reproduz a fala do pai para tornar vívidos tais sentimentos: "Meu pai tinha vezes que ele chorava. Ele começava a falar e chorava. Dizia 'eu me arrependo tanto, deles terem me conhecido, de eles ter tirado eu do mato, eu era feliz' [...]".

Sobreviventes do Extermínio, realizado na TI S. Jerônimo. Esse encontro foi resultado da parceria entre a Funai e a Universidade Estadual de Londrina (UEL), que se ocupou da documentação do evento. Durante aproximadamente dez dias, sete sobreviventes Tikuein, Ã, Rondon, Kuein, Tiguá, Tiquein Xetá e Ana Maria -, seus parentes, vizinhos e pessoas com as quais possuíam alianças sociais e políticas colocaram em cena a vida do mato: entre as atividades coletivas do encontro, construíram uma cozinha coletiva, empreenderam caçadas e caminhadas, prepararam assados de carne, tomaram banhos de rio e compartilharam histórias na língua nativa, que a maior parte deles ainda lembrava. pouco, em setembro de 2019, ocorreu na TI S. Jerônimo o terceiro Encontro Xetá. De qualquer maneira, é importante aqui notar que os encontros dos Xetá tiveram início na década de 1990 e, invariavelmente, contaram com o suporte dos pesquisadores com os quais estavam em diálogo.

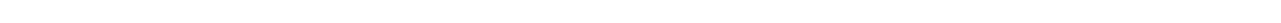


acervos passa a ser preponderante (Passos 2021). De lá para cá - portanto, até 2019 - novos encontros coletivos deixaram de acontecer e isto nos parece ter sido devido tanto à interrupção da constância dos pesquisadores por perto - sobretudo após a partida de Carmen Lúcia da Silva para o Mato Grosso, onde se tornou professora da UFMT - mas possivelmente também devido à perda de parentes fundamentais em suas lutas, quando os Xetá passaram por um longo e profundo período de luto e reclusão. ${ }^{13}$ No intervalo, os encontros cotidianos de convivência ou esporádicos (como visitas) entre eles não deixaram de acontecer, mas sim sua expressão coletiva, que só seria retomada em 2019, no período de realização de nossas próprias pesquisas. Assim, cabe frisar o quanto é notável a presença dos pesquisadores em suas vidas, sendo que não podemos deixar de lembrar que assim tem sido desde os primeiros anos do contato definitivamente estabelecido no final da década de 1940.

No último encontro, em 2019, surpreendeu-nos a disposição dos presentes para a necessária contação do que foi a vida no passado - um passado que, é preciso dizer, eles não viveram, mas não deixam nunca de lembrar. De fato, a missão de contar a história é um imperativo a que se dedicam os Xetá desde que foram tirados do mato. Vários deles se dispuseram a dar testemunhos diante de câmeras de vídeo, todos nascidos após o contato, no desterro. Ali estavam reunidas as duas gerações pós-desterro de Serra dos Dourados: os filhos dos desterrados e os filhos dos filhos dos desterrados. Os representantes dessas duas gerações insistiam em um mesmo discurso, diziam da importância do reencontro e de como a luta não está encerrada, e não estará enquanto não forem recuperadas ao menos partes de suas terras.

Naquela ocasião, encerradas as falas, ${ }^{14}$ passamos a ensaiar como deveríamos abordar Ã, que fora retirada ainda menina de Serra dos Dourados, em cima de um burro conduzido pelo funcionário do SPI, Dival José de Souza (Figura 3). Ã, como registraram muitos pesquisadores, é muito quieta, silenciosa, e evita falar do que viveu. Naquele encontro, era ela a única pessoa que efetivamente havia vivido as experiências que explicam o reencontro periódico. 
Fig. 3 - Ã sendo conduzida por Dival de Souza

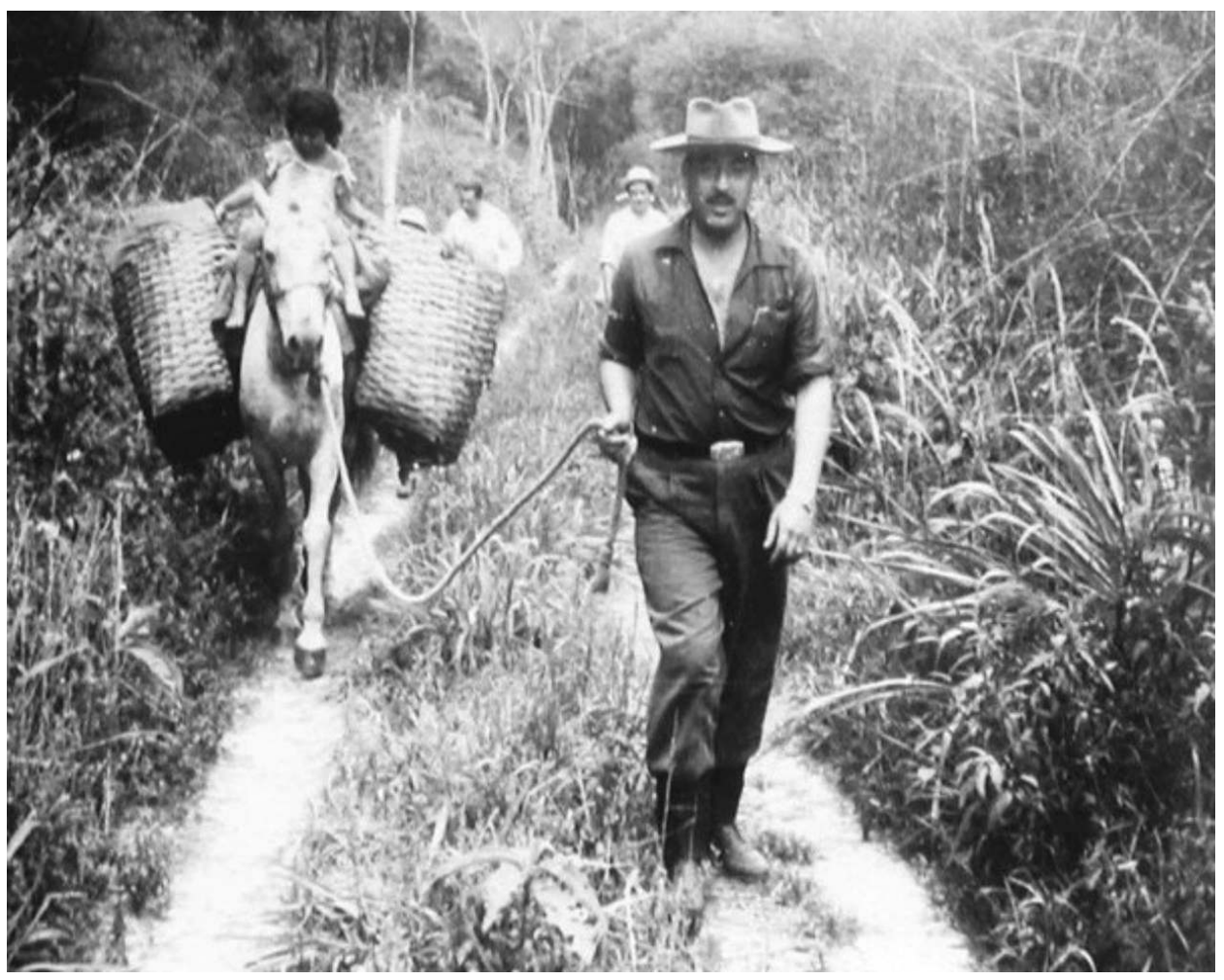

(foto Vladimir Kozák, 1955, acervo MAE/UFPR)

55 Surpreendendo a audiência, Ã deixou-se abordar por sua sobrinha Benedita (Figura 4) e deu-lhe extenso depoimento sobre sua vida no "mato", falando principalmente do que se comia e do temido espírito möw. Ã se dispôs a narrar sua história para que todos saibam, para que ninguém se esqueça, como asseverou à sobrinha ao final de sua fala mansa: "Isso é o que sei contar [...] já contei bastante. Nós somos parentes xetá, nós temos que contar, contar... Nós não vamos viver toda vida, um dia tenho que ir para onde meu irmão foi". 
Fig. 4 - Ã e Benedita no encontro Xetá

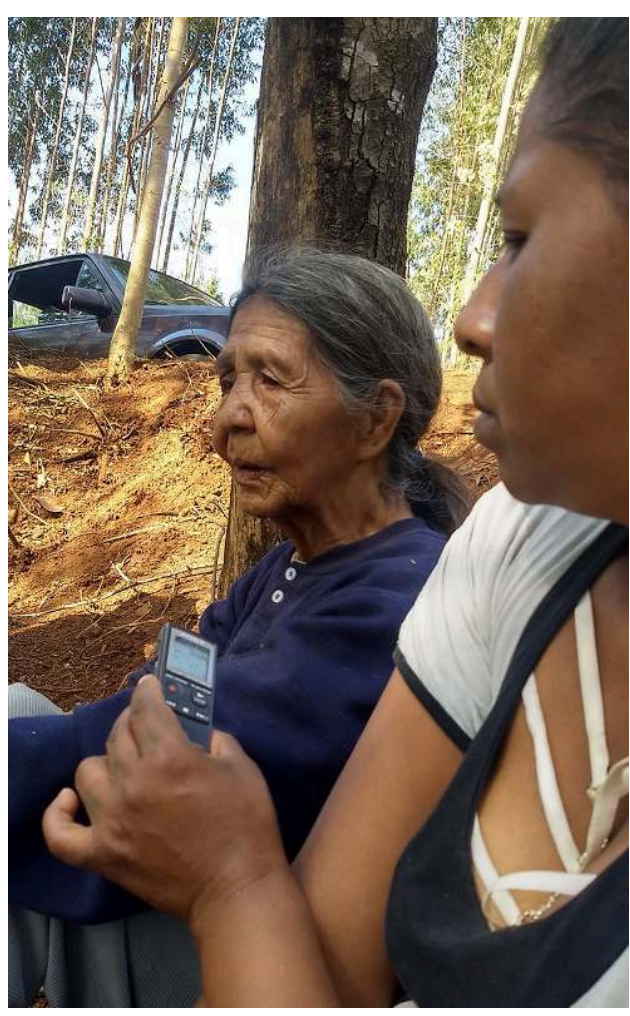

56 Naquele sábado, a velha Ã, finalmente, falava diante de muitas pessoas, entre seus parentes e pesquisadores que a ouviam e gravavam com atenção. E ela repetia a sina das outras crianças violentadas na cobiça da frente colonizadora, especialmente Kuein, Tuca e Tikuein: “é preciso falar, não podemos esquecer!". Falar, ali, estava fortemente e efetivamente associado ao ato de registrar -além do gravador empunhado por Benedita, sentada ao seu lado, havia muitos outros aparelhos capturando sua voz e sua imagem. Ao falar, Ã levava-nos ao seu passado, preocupava-se com a memória das atuais gerações, num prolongamento às futuras: para que não se esqueçam. Punha-se em ação a transmissão de conhecimentos. Benedita entrevistou sua própria tia diante de vários parentes..$^{15}$ Ã permitiu ser abordada e, com incontida satisfação, contava uma série de histórias, deixando claro que era preciso transmitir suas lembranças, garantindo-lhes que seriam guardadas pelos ouvintes, para que pudessem ser repetidas no futuro. Os fatos narrados pareciam interessar-lhe menos que o prolongamento deles na memória de seus descendentes.

Saber e lembrar, conhecimento e memória. Entre o passado da rememoração e o futuro da repetição, Ã opera inflexões no tempo que gravadores e etnógrafos não podem registrar, restando tão somente a estranha sensação de que naquele momento a narradora remetia, em passagens diretas, do passado ao futuro - à sua descendência, às gerações futuras. Enquanto Ã falava, a audiência silenciava, surpresa, dada a excepcionalidade de sua disposição à narração. Todos tinham clareza da potência e da importância do registro de suas raras palavras, que restarão guardadas em acervos digitalizados de museus e universidades, somando-se àqueles que se acumulam ao longo dos anos. 


\section{Seguir contando}

58 A carga afetiva das várias falas distribuídas ao longo de nosso texto nos conduz aqui a tomar emprestadas as indicações de Seligmann-Silva (2008), refletindo sobre o gesto testemunhal, no caso, de sobreviventes do Holocausto, que o autor afirmou se tratar efetivamente de seu trauma de um "passado que não passa".

Passado, presente e futuro relacionam-se sem se confundir, entremeiam-se para contar uma mesma história de usurpação e violência, incrustada na memória de nossos interlocutores. No passado, seguindo a narrativa de nossos amigos, está a vida pujante, vigorosa, livre, de seus pais e avós, até que a opressão colonial os alcançou, sua liberdade lhes foi confiscada, sua terra roubada e seus corpos violentados. No futuro, resta a esperança da reunião dos parentes em uma mesma terra, com o restabelecimento da dignidade dos Xetá organizados enquanto um povo autônomo. ${ }^{16}$ Como se pudéssemos dizer, então, que o presente resta em suspensão, como um intervalo. Resguardadas as especificidades culturais e geográficas, é como repetir as palavras de Santos-Granero (2007, p. 50) ao tratar dos Yanesha: "In brief, the Yanesha conceive of the present, timeriddled era as an interlude between a timeless past and a timeless future".

60 A experiência dos Xetá com as coleções formadas à época do contato apresenta-se como uma oportuna situação para reflexões em torno dos dilemas éticos e dos desafios políticos dados à efetiva repatriação de acervos para os povos indígenas. Nesse contexto, inscrito num campo mais amplo de luta da história e da memória coletivas, contra a ideia da "extinção", ocorre uma série de transformações substantivas, em peças, materiais, conhecimentos e conhecedores, bem como inflexões propriamente políticas, compreendendo o campo relacional que enreda, neste caso, povos indígenas, museus e antropologia, em que são alteradas as relações, por um turno, dos indígenas com museus e arquivos, e por outro, as próprias relações dessas instituições com os acervos (e as peças) que guardam e os conhecimentos que veiculam.

61 É a vida de afetos partilhada ao lado dos parentes no passado que os acervos digitais têm revelado aos Xetá no presente: são os tempos difíceis e árduos em que primeiramente foram separados, tiveram suas terras invadidas e usurpadas, depois foram estabelecidos em terras alheias e convertidos em trabalhadores rurais, quando passam então a transitar entre aldeias, reservas e cidades. Nos acervos estão as marcas também da solidão, da tristeza, do sofrimento, as marcas da morte e da ausência dos antigos. ${ }^{17}$ Ao mesmo tempo, em termos mais positivos, tais registros permitem também que se alcancem as trajetórias de vida, o cotidiano, os conhecimentos transmitidos, os momentos alegres dos reencontros, a rememoração da vida no mato. Nos processos de rememoração em que se enredam, elaboram-se narrativas nem sempre encadeadas de modo cronológico, tampouco sérico, mas, sempre que possível, são apresentados os nomes, as pessoas, os espaços, as relações de parentesco, as emoções e os afetos que perpassaram as experiências da vida entre parentes, ou suas ausências.

62 Se por ocasião da formação dos acervos, nas décadas de 1950 e 1960, os pesquisadores, a partir de uma leitura inegavelmente primitivista, tinham os Xetá como exemplares de uma etapa evolutiva - o que se atesta pela profusão de referência a eles como "os últimos índios da idade da pedra"-, contemporaneamente se alcança a coetaneidade (Fabian 2013), quando eles próprios frequentam os mesmos espaços, exploram os antigos acervos e propõem novas interpretações sobre objetos elaborados por seus parentes pretéritos. Sobretudo desde a apropriação de acervos digitais (Figura5), os Xetá 
conhecem, ao mesmo tempo em que formulam, novos entendimentos sobre seu passado, com forte expectativa de o reencontrarem futuramente. Isto não quer dizer que anseiem ou planejem reproduzir integralmente a vida de seus parentes do mato, mas sim que guardam expectativa de poderem viver novamente juntos. Apropriando-se progressivamente de seus acervos, estabelecendo o colecionismo como prática doméstica e empreendendo suas próprias investigações, os Xetá alteram nossa compreensão dos museus, retirando-os do lugar de proprietários dos objetos que detêm. Sem negar sua importância, os museus são compreendidos como locais de guarda dos objetos, como depósitos, por assim dizer, de suas histórias, e certificam, de maneira surpreendente, a existência do coletivo Xetá, e não seu desaparecimento - contrariando (e ampliando) então a imaginação dos pesquisadores que, para sua sorte, formaram as primeiras coleções. Sem elas, possivelmente a história seria outra.

Fig. 5 - Reunidos em frente à casa do cacique, famílias xetá assistem filmes de Vladimir Kozák, em cópias digitais obtidas junto ao Museu Paranaense (Mupa), na Terra Indígena São Jerônimo, durante o "Encontro do Povo Xetá" (2019)

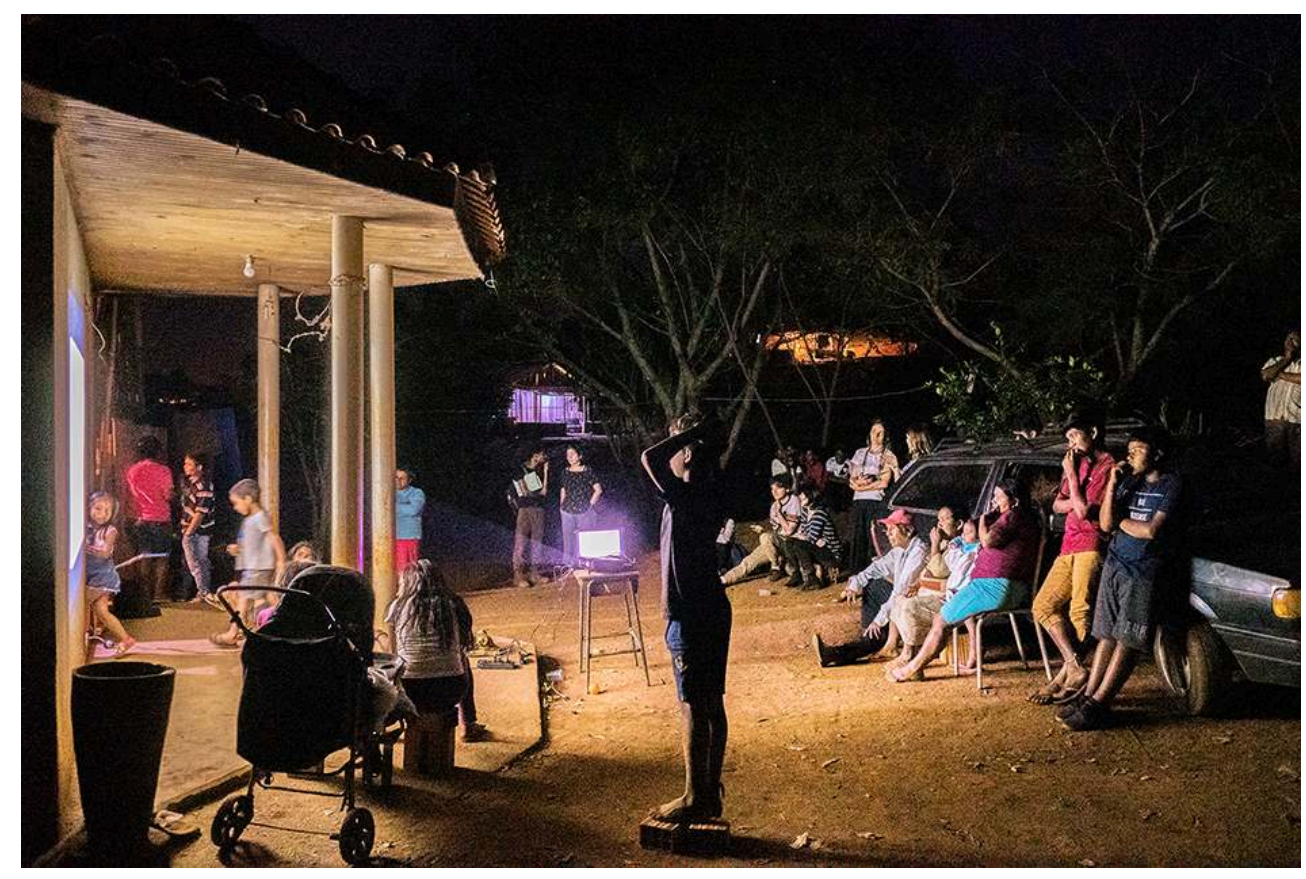

(foto Douglas Fróis, 2019)

\section{BIBLIOGRAFIA}

BENETTI Rosalice C.

2016 Vladimir Kozák. Sentimentos e ressentimentos de um "lobo solitário", Sociedade de Amigos do

Museu Paranaense, Curitiba. 
CARNEIRO DA CUNHA Manuela (org.)

2009 “'Cultura' e cultura: conhecimentos tradicionais e direitos intelectuais", in Cultura com aspas, Cosac Naify, São Paulo, p. 311-373.

\section{FABIAN Johannes}

2013 O tempo e o outro: com a antropologia estabelece seu objeto, Vozes, Petrópolis.

\section{FERNANDES José Loureiro}

1959 “Os índios da Serra dos Dourados (Os Xetá)", in Anais da III Reunião Brasileira de Antropologia, [Recife, 10 a 13 de fevereiro], p. 27-46.

FERNANDES José Loureiro

1962 "The Xetá - the dying people in Brazil", Bulletin of the International Commitee on Urgent Anthropological Research (Vienna), 5, p. 151-154.

KOZÁK Vladimir

s.d. A história dos Xetá, ms., acervo do Museu Paranaense, Curitiba.

KOZÁK Vladimir, David BAXTER, Laila WILLIAMSON e Robert CARNEIRO

1981 "Hetá: peixe em lagoa seca", Boletim do Instituto Histórico e Geográfico Paranaense. Curitiba, 38, p. 9-120.

LAMING-EMPERAIRE Annette, Maria José MENEZES e Margarida Davina ANDREATA

1978 “O Trabalho da pedra entre os Xetá da Serra dos Dourados, Estado do Paraná”, in Coletânea de estudos em homenagem a Annette Laming-Emperaire, Universidade de São Paulo, Fundo de Pesquisas do Museu Paulista (Coleção Museu Paulista, série ensaios, 2), São Paulo, p. 19-82.

LEITE Gian Carlo Teixeira

2019 "Do contato aos dias atuais: sete décadas de notícias sobre os Xetá da Serra dos Dourados", Sociologias Plurais, 5 (1), p. 343-367.

LIMA Edilene Coffaci de

2016 "Exílios índios: sobre deslocamentos compulsórios no período militar", Aceno. Revista de Antropologia, 3, p. 18-35.

LIMA Edilene Coffaci de

2018 "De documentos etnográficos a documentos históricos: a segunda vida dos registros sobre os Xetá", Sociologia \& Antropologia, Rio de Janeiro, 8 (2), p. 571-597.

LIMA Edilene Coffaci de e Gian Carlo Teixeira LEITE

2019 “Justiça de Transição e os Xetá: sem anacronismos", Campos, 20 (2), p. 123-234, https:// revistas.ufpr.br/campos/article/view/71857/pdf, acesso em 01/06/2021.

LIMA Edilene Coffaci de e Rafael PACHECo

2017a "Povos indígenas e justiça de transição: reflexões a partir do caso Xetá", Aracê - Direitos humanos em revista, 5, p. 219-240.

LIMA Edilene Coffaci de e Rafael PACHECo

2017 b “Acervos e memória xetá: 'como a gente vivia”, comunicação apresentada ao Seminário 25 anos de História dos Índios no Brasil: balanço e perspectivas da questão indígena (Mesa 9 - Novas fontes), Centro de Estudos Ameríndios da USP/Centro de Pesquisa em Etnologia Indígena da Unicamp, São Paulo, ms.

\section{MERENCIO Fabiana Terhaag}

2014 Tecnologia lítica xetá: um olhar arqueológico para a coleção etnográfica de lítico lascado e polido 
do MAE-UFPR, Programa de Pós-Graduação em Antropologia (Maîtrise), Setor de Ciências Humanas, Universidade Federal do Paraná, Curitiba (PR).

MOTA Lúcio Tadeu

2013 Os Xetá do vale do rio Ivaí - 1840-1920, EDUEM, Maringá.

MOTA Lúcio Tadeu e Rosângela FAUSTINo

2018 O SPI e os Xetá na Serra dos Dourados - PR. Acervo documental, EDUEM, Maringá.

PACHECO Rafael

2018 Os Xetá e suas histórias: memória, estética e luta desde o exilio, Programa de Pós-Graduação em Antropologia (Maîtrise), Setor de Ciências Humanas, Universidade Federal do Paraná, Curitiba (PR).

PARELLADA Claudia Inês

2017 "Plumária, peles, lascas e cerume de abelha: diálogos entre arqueologia guarani e povos Xetá”, Pesquisas, Antropologia (Instituto Anchietano de Pesquisas, São Leopoldo), 73, p. 213-234, http://www.anchietano.unisinos.br/publicacoes/antropologia/antropologia73/010.pdf, acesso em $01 / 06 / 2021$.

\section{PASsos Lilianny Rodriguez Barreto dos}

2021 “As coisas xetá: pessoas, instituições e coleções”, Programa de Pós-Graduação em Antropologia, Setor de Ciências Humanas, Universidade Federal do Paraná, Curitiba (PR).

\section{RosATo Márcia Cristina}

2009 Uma constelação de imagens. A experiência etnográfica de Vladimir Kozák, Tese de doutorado, Sociologia, Universidade Federal do Paraná, Curitiba (PR).

\section{SANTOS-GRANERo Fernando}

2007 "Time is disease, suffering and oblivion. Yanesha historicity and the struggle against temporality", in Carlos Fausto e Michael Heckenberger, Time and memory in indigenous Amazonia. Anthropological perspectives, University Press of Florida, Gainesville.

\section{SELIGMANN-SILVA Márcio}

2008 "Narrar o trauma - a questão dos testemunhos de catástrofes históricas", Psicologia Clínica, $20(1)$, p. 65-82.

\section{SILVA Carmen Lúcia da}

1998 Os Xetá: sobreviventes do extermínio, Dissertação de Mestrado em antropologia social, Universidade Federal de Santa Catarina, Florianópolis (SC).

\section{SILVA Carmen Lúcia da}

2003 Em busca da sociedade perdida: o trabalho da memória Xetá, Tese de doutorado em Antropologia, Universidade de Brasília, Brasília.

SouZA Luana Maria

2017 Contextos e processos de formação de formação da coleção Xetá do Museu de Arqueologia e Etnologia da UFPR-MAE-UFPR, Monografia (Graduação em Ciências Sociais) -Universidade Federal do Paraná, Curitiba (PR).

\section{SPENASSATTo Josiéle Andrea}

2016 Os lados da mistura. Desafios da coabitação e intercasamentos na Terra Indígena São Jerônimo (PR/Brasil), Dissertação de Mestrado em Antropologia Social, Universidade Federal do Paraná, Curitiba (PR).

\section{WAGNER Roy}

1975 The invention of culture, University of Chicago Press, Chicago. 
BENETTI Rosalice C.

2016 Vladimir Kozák. Sentimentos e ressentimentos de um "lobo solitário", Sociedade de Amigos do Museu Paranaense, Curitiba.

CARNEIRO DA CUNHA Manuela (org.)

2009 “'Cultura' e cultura: conhecimentos tradicionais e direitos intelectuais", in Cultura com aspas, Cosac Naify, São Paulo, p. 311-373.

\section{FABIAN Johannes}

2013 O tempo e o outro: com a antropologia estabelece seu objeto, Vozes, Petrópolis.

FERNANDES José Loureiro

1962 "The Xetá - the dying people in Brazil", Bulletin of the International Commitee on Urgent Anthropological Research (Vienna), 5, p. 151-154.

FERNANDES José Loureiro

1959 “Os índios da Serra dos Dourados (Os Xetá)”, in Anais da III Reunião Brasileira de Antropologia, [Recife, 10 a 13 de fevereiro], p. 27-46.

KOZÁK Vladimir, David BAXTER, Laila WILLIAMSON e Robert CARNEIRO

1981 "Hetá: peixe em lagoa seca", Boletim do Instituto Histórico e Geográfico Paranaense. Curitiba, 38, p. 9-120.

KozÁK Vladimir

s.d. A história dos Xetá, ms., acervo do Museu Paranaense, Curitiba.

LAMING-EMPERAIRE Annette, Maria José MENEZES e Margarida Davina ANDREATA

1978 "O Trabalho da pedra entre os Xetá da Serra dos Dourados, Estado do Paraná”, in Coletânea de estudos em homenagem a Annette Laming-Emperaire, Universidade de São Paulo, Fundo de Pesquisas do Museu Paulista (Coleção Museu Paulista, série ensaios, 2), São Paulo, p. 19-82.

LEITE Gian Carlo T.

2019 "Do contato aos dias atuais: sete décadas de notícias sobre os Xetá da Serra dos Dourados", Rev. Sociologias Plurais, 5 (1), p. 343-367.

LIMA Edilene Coffaci de

2016 "Exílios índios: sobre deslocamentos compulsórios no período militar", Aceno. Revista de Antropologia, 3, p. 18-35.

\section{LIMA Edilene Coffaci de}

2018 "De documentos etnográficos a documentos históricos: a segunda vida dos registros sobre os Xetá", Sociologia \& Antropologia, Rio de Janeiro, 8 (2), p. 571-597.

\section{LIMA Edilene Coffaci de e Gian Carlo Teixeira LEITE}

2019 “Justiça de Transição e os Xetá: sem anacronismos”, Campos, 20 (2), p. 123-234, https:// revistas.ufpr.br/campos/article/view/71857/pdf, acesso em 01/06/2021.

LIMA Edilene Coffaci de e Rafael PACHECo

2017a "Povos indígenas e justiça de transição: reflexões a partir do caso Xetá", Aracê - Direitos humanos em revista, 5, p. 219-240.

\section{LIMA Edilene Coffaci de e Rafael PACHECO}

2017 b “Acervos e memória xetá: 'como a gente vivia”, comunicação apresentada ao Seminário 25 anos de História dos Índios no Brasil: balanço e perspectivas da questão indígena (Mesa 9 - Novas fontes), Centro de Estudos Ameríndios da USP/Centro de Pesquisa em Etnologia Indígena da Unicamp, São Paulo, ms. 


\section{MERENCIO Fabiana Terhaag}

2014 Tecnologia lítica xetá: um olhar arqueológico para a coleção etnográfica de lítico lascado e polido do MAE-UFPR, Programa de Pós-Graduação em Antropologia (Maîtrise), Setor de Ciências Humanas, Universidade Federal do Paraná, Curitiba (PR).

\section{MOTA Lúcio Tadeu}

2013 Os Xetá do vale do rio Ivaí - 1840-1920, EDUEM, Maringá.

\section{MOTA Lúcio Tadeu e Rosângela FAUSTINO}

2018 O SPI e os Xetá na Serra dos Dourados - PR. Acervo documental, EDUEM, Maringá.

\section{PACHECO Rafael}

2018 Os Xetá e suas histórias: memória, estética e luta desde o exilio, Programa de Pós-Graduação em Antropologia (Maîtrise), Setor de Ciências Humanas, Universidade Federal do Paraná, Curitiba (PR).

\section{PARELLADA Claudia Inês}

2017 "Plumária, peles, lascas e cerume de abelha: diálogos entre arqueologia guarani e povos Xetá", Pesquisas, Antropologia (Instituto Anchietano de Pesquisas, São Leopoldo), 73, p. 213-234, http://www.anchietano.unisinos.br/publicacoes/antropologia/antropologia73/010.pdf, acesso em $01 / 06 / 2021$.

\section{PASSOS Lilianny Rodriguez Barreto dos}

2021 “As coisas xetá: pessoas, instituições e coleções”, Programa de Pós-Graduação em Antropologia, Setor de Ciências Humanas, Universidade Federal do Paraná, Curitiba (PR).

\section{Rosato Márcia Cristina}

2009 Uma constelação de imagens. A experiência etnográfica de Vladimir Kozák, Tese de doutorado, Sociologia, Universidade Federal do Paraná, Curitiba (PR).

\section{SANTOS-GRANERO Fernando}

2007 "Time is disease, suffering and oblivion. Yanesha historicity and the struggle against temporality", in Carlos Fausto e Michael Heckenberg, Time and memory in indigenous Amazonia. Anthropological perspectives, University Press of Florida, Gainesville.

\section{SELIGMANN-SILVA Márcio}

2008 "Narrar o trauma - a questão dos testemunhos de catástrofes históricas", Psic. Clínica, $20(1)$, p. 65-82.

\section{SILVA Carmen Lúcia da}

1998 Os Xetá: sobreviventes do extermínio, Dissertação de Mestrado em antropologia social, Universidade Federal de Santa Catarina, Florianópolis (SC).

\section{SILVA Carmen Lúcia da}

2003 Em busca da sociedade perdida: o trabalho da memória Xetá, Tese de doutorado em Antropologia, Universidade de Brasília, Brasília.

\section{SouZA Luana Maria}

2017 Contextos e processos de formação de formação da coleção Xetá do Museu de Arqueologia e Etnologia da UFPR-MAE-UFPR, Monografia (Graduação em Ciências Sociais) -Universidade Federal do Paraná, Curitiba (PR).

\section{SPENASSATTo Josiéle Andrea}

2016 Os lados da mistura. Desafios da coabitação e intercasamentos na Terra Indígena São Jerônimo (PR/Brasil), Dissertação de Mestrado em Antropologia Social, Universidade Federal do Paraná, Curitiba (PR). 
WAGNER Roy

1975 The invention of culture, University of Chicago Press, Chicago.

\section{Documentos}

CNV (COMISSÃO NACIONAL DA VERDADE, Brasil)

2014 "Violação dos direitos humanos dos povos indígenas", Relatório: textos temáticos, CNV, Brasília, 2 vols, v. 2, p. 197-256.

FUNAI (FUNDAÇÃO NACIONAL DO ÍNDIO)

2013 Relatório Circunstanciado de Identificação e Delimitação da Terra Indígena Herarekã Xetá, FUNAI, Brasília (DF), 30 de junho.

CEV-PR (COMISSÃo ESTADUAL DA VERDADE TERESA URBAN, Paraná)

2017 Violações de direitos humanos contra povos indígenas, Relatório da Comissão Estadual da Verdade do Paraná/Comissão Estadual da Verdade do Paraná Teresa Urban, Curitiba.

SILVA Carmen Lúcia da (coord.)

1997 Encontro Xetá: Sobreviventes do Extermínio, Relatório, Acervo do Instituto Socioambiental, São Paulo, Ref.: XTD00011.

\section{Filmes}

FERNANDES José Loureiro

196- Os Xetá da Serra dos Dourados, Departamento de Antropologia, Universidade Federal do Paraná, Serra dos Dourados.

\section{NOTAS}

1. O então Serviço de Proteção aos Índios e Localização de Trabalhadores Nacionais (SPILTN, posteriormente SPI), foi criado em 1910 como o órgão público federal destinado à execução da política indigenista do Estado. Foi extinto em 1967, dando lugar à atual Fundação Nacional do Índio (Funai).

2. Kozák conhecera Robert Carneiro e Gertrude Dole num voo da Força Aérea Brasileira (FAB) para o Xingu em 1953 (Benetti 2016, p. 175). A possibilidade de Alfred Métraux ir ao Paraná - não realizada em virtude de compromissos universitários - está sugerida nas correspondências com o casal Carneiro e Dole do segundo semestre de 1962, hoje no acervo do Museu Paranaense (Mupa).

3. A partir daqui usaremos itálicos para destacar palavras em português (mas também em xetá, quando for o caso) usadas recorrentemente pelos próprios xetá contemporâneos para narrar suas disputas em torno de seu reconhecimento étnico e fundiário, que andam praticamente juntos. Estão em itálicos, entre outras, luta, liderança, trabalhos, artesanato, antigos, misturados, parentes, mato, história, contação e fala. Em itálico também estão os títulos originais de obras que mencionamos. Reservamos as aspas para as citações de suas próprias falas ou dos autores que escreveram sobre eles.

4. Apesar do status de língua ameaçada, o xetá é bem documentado. Nas expedições organizadas por José Loureiro Fernandes, acompanhava-o o linguista Aryon Dall'Igna 
Rodrigues, curitibano, que muito mais tarde se tornaria um dos maiores especialistas em línguas indígenas no Brasil. Dall'Igna Rodrigues esteve com os Xetá entre 1960, 1962 e em 1967. Retomou seus trabalhos linguísticos com os Xetá no início deste século, pouco antes de sua morte em 2014. Seus materiais de pesquisa estão depositados no Laboratório de Línguas e Literaturas Indígenas (LALLI) da UnB, por ele próprio fundado em 1999. Tais materiais interessam aos Xetá, e fomos solicitados a ajudá-los a alcançá-los, algo adiado por força da pandemia do novo coronavírus e das exigências de isolamento social.

5. Decreto n. 50.665/1951. Disponível em https://www2.camara.leg.br/legin/fed/decret/ 1960-1969/decreto-50665-30-maio-1961-390248-publicacaooriginal-1-pe.html, acesso em 1 de junho de 2021.

6. A partir da documentação é possível saber que boa parte dos objetos em acervos foi obtida sem qualquer permissão dos Xetá. Os pesquisadores simplesmente pegaram-nos em acampamentos que o grupo deixava às pressas, em fuga, ao notar a aproximação dos visitantes, razão pela qual nos parece apropriado falar em pilhagem ou roubo.

7. A definição da dispersão dos Xetá como extravio compõe o vocabulário em português dos Xetá contemporâneos, mas antes apareceu também no artigo de Laming-Emperaire, Menezes e Andreatta (1978).

8. Os métodos de confecção desses objetos estão sendo registrados em vídeo, no âmbito de um projeto de fomento à produção comercial de "artesanato indígena" da Funai, com execução colaborativa do psicólogo e educador Paulo C. R. Ramom (PUC-PR). Sobre o colar de nó de pinho que atualiza um colar sipál e a história do homem que virou onça, veja-se Pacheco (2018, p. 174-176).

9. Liderança é um termo utilizado para designar figuras que constituem a estrutura e o conjunto de posições de poder e representação política das famílias e do povo Xetá em diversos ambientes sociais e instâncias de representação, negociação e deliberação, abrangendo o cacique (liderança principal ou chefe), o vice-cacique (segundo hierárquico) e as lideranças mesmo, que são subordinadas ao primeiro. As pessoas jovens, por estarem em fase de formação, não são autorizadas, ou encorajadas, a representar publicamente o povo e a conduzir a narrativa histórica oficial como seus porta-vozes, segundo as lideranças titulares (ver Spenassatto 2016; Pacheco 2018).

10. É preciso notar aqui a provisoriedade dos próprios planos que fazem as lideranças, dado que pensam na construção do centro cultural em São Jerônimo apenas em virtude do fato de que a demarcação de suas terras resta em suspenso, tendo estas sido identificadas, mas não homologadas, nas proximidades de Serra dos Dourados (Funai 2013). No atual contexto político brasileiro, sua homologação apresenta-se, de fato, ameaçada.

11. A compreensão como relíquia prende-se exclusivamente ao fato de que os objetos contidos nos acervos digitais condensam a vida dos antigos, de seus parentes do mato, sem qualquer conteúdo religioso, colocando em destaque a estima que carregam.

12. Em outro lugar, Lima (2018) abordou a transformação dos acervos xetá. Pensados por Loureiro Fernandes e Kozák, os principais pesquisadores à época do contato, como documentos etnográficos, hoje os acervos são apropriados pelos próprios Xetá como documentos históricos.

13. Pensamos aqui especialmente na morte de Tikuein (José Luciano da Silva), em 2005, e de Tuca (Tucanambá Paraná), em 2007.

14. Fala designa geralmente um discurso público (Pacheco 2018). 
15. O grupo de parentes sobreviventes da Serra dos Dourados - ̃̃, Kuein, Tikuein (Mã) e Tuca - consideram-se uns aos outros como primos, devido à relação que seus genitores mantinham entre si antigamente. Os filhos destes, as atuais gerações, consideram-nos como seus tios (também primos do pai).

16. Sobre a noção de autonomia, na reflexão histórico-política dos Xetá, veja-se Silva (1998, 2003) e Pacheco (2018), e de modo mais geral, na política da TI S. Jerônimo, veja-se Spenassatto (2016).

17. A ausência aí deve ser relativada, uma vez que há constante presentificação dos antigos, em diversas e distintas formas e circunstâncias. No limite, poderia tratar-se de uma presença-ausência, sendo que sua presença, inicialmente condicionada ao passado de sua existência material ("física"), extrapola os limites da matéria, fazendo-se presente também em sonhos e, às vezes, reverberando a partir de objetos - "é como se eu sentisse eles, os antigos, aqui comigo" diz Claudemir na reserva técnica do MAE/UFPR ao interagir com a coleção de cultura material dos Xetá.

\section{RESUMOS}

Em meados do século $\mathrm{xx}$, os Xetá, povo indígena falante de uma língua tupi-guarani, foram contatados no Sul do Brasil, e subitamente reduzidos: em uma década perderam $70 \%$ de sua população. Do contato restou farta documentação sobre o grupo, que cobre diversificados interesses: cultura material, cinema, etnomusicologia, arqueologia e linguística. Refeitos demograficamente, embora ainda desterritorializados, os Xetá têm cada vez mais buscado conhecer os acervos depositados em museus, os quais documentam a trágica história do grupo, que vai, assim, tomando uma forma cristalizada e irrevogável. $\mathrm{Na}$ atualidade, emulando os antigos, os grupos familiares xetá estão a (re)produzir machados de pedra, bichinhos, pontas de flechas, colares, e colecionando filmes e fotografias em que se busca recuperar a vida passada. Concebidas entre as categorias "trabalho" e "relíquia", essa produção lhes permite dinamizar a vida social, instaurando uma lógica objetiva e subjetiva, permeada de temporalidade e constitutiva da vida xetá. A partir da dinâmica de relações entre essas categorias, este artigo pretende refletir o modo como "as coisas dos antigos no tempo do mato" criam a vida, isto é, movimentam e revelam, em termos de enunciação de conceitos, as relações, a política, o afeto, a memória e a temporalidade xetá.

Au milieu du siècle dernier, les Xetá du sud du Brésil, locuteurs d'une langue tupi-guarani, ont été contactés et brutalement décimés: en une décennie, ils ont perdu $70 \%$ de leur population. Depuis le contact, une vaste documentation a été collectée sur ce groupe, qui couvre de nombreux champs, sous diverses formes: culture matérielle, cinéma, ethnomusicologie, archéologie et linguistique. Sauvés sur le plan démographique, bien que toujours privés de territoire, les Xetá cherchent à prendre connaissance des collections déposées dans les musées, et documentent leur histoire tragique, qui prend ainsi une forme cristallisée et irrévocable. Aujourd'hui, imitant les anciens, les groupes familiaux xetá (re)produisent des haches de pierre, des animaux miniatures, des pointes de flèches, des colliers, et rassemblent des films et des photographies afin d'y retrouver des éléments du passé. Conçue entre les catégories de «travail» et de «relique ", cette production leur permet de dynamiser leur vie sociale en y 
instaurant une logique, objective et subjective, propre à la vie xetá et à ses concepts de temporalité. À partir de la tension entre ces catégories, cet article examine la façon dont «les choses des anciens du tempss de la forêt ", créent la vie, au sens où - conceptuellement et relationnellement - ces objets animent et éclairent la politique, l'affectivité, la mémoire et la temporalité.

In the middle of the last century, the Xetá, speakers of a Tupi-Guarani language of southern Brazil, were contacted and rapidly decimated, losing $70 \%$ of their population in the course of a decade. During those years, vast amounts of documentation about the group were collected (films, artefacts, sound recordings...), covering a wide range of fields (ethnomusicology, archaeology, linguistics...). Though still deterritorialized, the Xetá have now demographically recovered and show growing interest in the collections deposited in museums, which document their tragic history, enshrined in a crystallized and irrevocable form. Nowadays, emulating their forebears, Xetá family groups (re) produce stone axes, animal figurines, arrowheads, necklaces, and they collect films and photographs in which past life is recovered. Categorized somewhere between "work" and "relics", this production is key to the dynamics of their social life and establishes a sort of logic, both objective and subjective, permeated by concepts of temporality. Reflecting on these dynamics, this article intends to show how "the things of the times when our forebears lived in the forest" create life; in other words, how they reconfigure the Xetá's political, social, emotional, memorial and temporal lives.

\section{ÍNDICE}

Keywords: Xetá, museums, collections, history

Mots-clés: Xetá, musées, collections, histoire

Palavras-chave: Xetá, museus, acervos, história

\section{AUTORES}

\section{EDILENE COFFACI DE LIMA}

Professora Titular, Departamento de Antropologia e Programa de Pós-graduação em Antropologia e Arqueologia da Universidade Federal do Paraná (PPGAA/UFPR), Brasil

\section{LILIANNY RODRIGUEZ BARRETO DOS PASSOS}

Doutora em Antropologia e Arqueologia, Secretaria da Educação e do Esporte, Paraná, Brasil

\section{RAFAEL PACHECO}

Doutorando, Programa de Pós-graduação em Antropologia Social da Universidade de São Paulo (PPGAS/USP), Brasil 